\title{
Connoisseurship and the Communication of Anatomical Knowledge: the Case of William Cheselden's Osteographia (1733)
}

\section{Alexander Wragge-Morley}

\begin{abstract}
:
This piece re-examines the connections between connoisseurship and anatomical knowledge in the works of the elite medics of eighteenth century Britain. These medics, including Richard Mead and William Cheselden, were known both for their medical innovations and for their commitment to the practices of connoisseurship - the collection and criticism of fine art objects.

Here I discuss the making, presentation and reception of one such object, the Osteographia (1733), a luxurious anatomical atlas produced by the famous surgeon William Cheselden and sharply criticised by another surgeon, John Douglas. Focusing on how these two surgeons engaged with the aesthetic and material qualities of the book, I identify hitherto overlooked connections between the much-contested discourses and practices of medical knowledge and connoisseurship.
\end{abstract}


It has often been claimed that eighteenth-century Britain witnessed a growing separation of artistic and scientific concerns. As the philosopher Jerome Stolnitz and many others have shown, the first half of the century witnessed the emergence of an autonomous aesthetic discourse, accompanying the emergence of a viable art market and of artistic institutions. Articulated by thinkers such as Joseph Addison, Anthony Ashley Cooper, $3^{\text {rd }}$ Earl of Shaftesbury, and the moral philosopher Frances Hutcheson, this discourse idealized artistic appreciation as a disinterested pursuit of beauty, unburdened by material or financial considerations. ${ }^{1}$ Such claims about the growing autonomy of the arts dovetail neatly with the equally widespread suggestion that, at exactly the same time, natural philosophers (the closest thing in the eighteenth century to scientists) were starting to see powerful affective experiences as having no place in scientific work. Lorraine Daston and Katharine Park have, for example, shown that many natural philosophers working in the eighteenth century came to see such experiences as prejudicial to calm, rational and useful scientific inquiry. ${ }^{2}$ Arguments for the growing autonomy of the arts and sciences in the early eighteenth century have therefore been founded on the emergence of aesthetics as an intellectual discipline, paradoxically linked to the emergence of artistic commerce and institutions, and the apparent simultaneous hollowing out of the aesthetic content of the sciences.

Notwithstanding the continued influence of these broad claims, it is in fact well known that there were deep and persistent connections between the arts and sciences in the eighteenth century, connections which found intellectual, technical and social expressions. ${ }^{3}$ In this piece I reconsider a body of evidence that has long proved difficult to incorporate into narratives of the emergence of the arts and sciences in their modern, autonomous forms - the mixture of aesthetic and scientific concerns that characterised the lives and works of Britain's elite medics in the eighteenth century. Many of the most successful medics of eighteenth century Britain, including the physicians Richard Mead (1673-1754) and John Woodward 
(1665/67-1728), along with the surgeon William Cheselden (1688-1752), were committed to collecting and discussing material things of perceived value - paintings, drawings, prints, books and antiquities. They were important connoisseurs of the arts in their own rights, and they backed up their commitment with considerable financial and social capital. ${ }^{4}$

While scholars have paid attention to the fact that eighteenth-century medics invested time, effort and money in the connoisseurship of art, antiquities and books, they have not generally appreciated the extent to which these activities informed the communication of medical knowledge itself. The best-known work on this subject is an essay by Ludmilla Jordanova concerning the choices in portraiture by the wealthy collector-physician Richard Mead. Over the course of his life, Mead gathered an enormous collection of paintings, drawings, prints, books, busts, medals and gems. Jordanova shows that Mead used his collection to draw attention to aspects of his identity as a medical practitioner in highly specific ways. ${ }^{5} \mathrm{He}$ used ancient coins apparently bearing representations of physicians, for example, to argue that medics of his own day ought to be accorded greater esteem by society. Mead used his collection of coins and medals, so to speak, as an instrument for defining his own social standing and that of physicians in general. By surveying patterns in Mead's acquisition and display of portraits, Jordanova shows that eighteenth century medics used connoisseurship to shape their social standing and thus their authority as medical practitioners. $^{6}$

Here I will push questions about the interconnections between connoisseurship and medical knowledge in a different direction. While acknowledging the tremendous value of Jordanova's demonstrations of the imbrication of connoisseurship with the social and cultural world of elite medics, I suggest that the links she has identified ran even deeper. I do this by discussing in detail a beautiful and expensive anatomical atlas produced by the surgeon 
William Cheselden, Osteographia, or the Anatomy of the Bones, published in 1733. Cheselden advertised it for subscription in 1727 , alerting potential subscribers that his proposed book would be as much a beautiful and expensive art object as a source of authoritative osteological knowledge. ${ }^{7}$ I do not intend to restate the familiar, and entirely valid, argument that Cheselden, in common with other surgeons of his time, sought to raise the status of their discipline by associating it with the world of luxurious books, prints and works of art. ${ }^{8}$ Instead, through a close engagement with the materiality of the Osteographia, I will uncover some of the connections made by Cheselden and his readers between the performance of connoisseurship, and the communication of useful anatomical knowledge.

One demonstration of these connections will be sought in Cheselden's own discussion of his book, in which, promiscuously mixing claims to ingenuity in connoisseurship and anatomy alike, he urged his readers to interpret the beauty and cost of the Osteographia as a sign of his own abilities as a philosopher of nature. I will also turn, however, to the only extended response to the book that has come down to us - one that has received virtually no scholarly attention. This is a pamphlet entitled Animadversions on a Late Pompous Book, Intituled, Osteographia: or, The Anatomy of the Bones (1735), by the surgeon John Douglas (d. 1743). ${ }^{9}$ Sharply satirical in tone, this little pamphlet bursts the bubble of Cheselden's book through an assay of its entire materiality - from the text, to the absence of page numbers, to every single one of its many illustrations. Douglas used his observations on the Osteographia to demonstrate that Cheselden had defrauded the book's purchasers by attempting to pass off as beautiful and useful something that was, in reality, ugly and useless. Indeed the qualities that he identified in the book's prints - ugliness, inutility, and excessive luxury - stood as powerful arguments against Cheselden's ability to make a range of judgments, including those concerning surgery and anatomy. Thus Douglas employed acts of connoisseurship to cast doubt on Cheselden's authority as a surgeon and anatomist, and vice-versa. 


\section{Cheselden and his Osteographia}

William Cheselden's fame has endured to our own times because of his contribution to eighteenth-century debates about vision and cognition. His report of what happened when, in 1728 , he restored sight to a boy who had been blind since birth, had immense significance for subsequent philosophical discussions concerning the interplay between sensation, cognition and the emotions, along with aesthetic theory. ${ }^{10}$ In his own time, however, Cheselden was famous mainly as a surgeon, largely on account of his improvements to, and skills in, the surgical procedure for removing bladder stones - lithotomy. In 1723 Cheselden reported on his successes in using a method of lithotomy devised by John Douglas in a short book, A Treatise on the High Operation for the Stone (1723). ${ }^{11}$ Although Cheselden acknowledged his debt to Douglas's work, Douglas nevertheless took umbrage at what he saw as the appropriation of his priority. This is indicated by the appearance in the same year of a short pamphlet by Robert Houston with the title Lithotomus castratus; or, Mr. Cheselden's treatise on the high operation for the stone, throughly examin'd, and plainly found to be Lithotomia Douglassiana (1723). Dedicated to the physician and satirist John Arbuthnot (bap. 1667 1735), this pamphlet sets out to show that Cheselden had falsely claimed Douglas's procedure as his own. ${ }^{12}$ By 1725 , Cheselden had in fact altered Douglas's procedure significantly (and for the better), as was advertised in pamphlets written by Cheselden's partisan James Douglas, the brother (confusingly) of John Douglas. ${ }^{13}$

The attacks made by John Douglas and his supporters did little to sully Cheselden's reputation. His second published work, The Anatomy of the Humane Body (1713) was republished continuously during the eighteenth century, serving effectively as the standard Anglophone anatomical textbook. ${ }^{14}$ In common with many other successful medics of eighteenth century London (such as his close friend Richard Mead), Cheselden maintained 
interests in art and connoisseurship that transgress modern disciplinary boundaries. It is clear that he had much more than a passing interest in fine art and that he had at least some mastery of its discourses and practices. Moreover, there is quite a lot of evidence to suggest that Cheselden's contemporaries saw him as a man of good judgment in architecture, art and belles lettres. From 1720 to 1724 Cheselden made a study of drawing, attending classes at the academy of art run by the painter Louis Chéron and the portraitist John Vanderbank. Ilaria Bignamini and Martin Postle have suggested that the Huguenot painter Chéron modified his approach to anatomical studies as a result of his interactions with Cheselden. ${ }^{15}$ Cheselden also counted some of the leading artists of the day, including William Hogarth and Jonathan Richardson, as friends. ${ }^{16}$

From almost the beginning of his career in the publication of anatomical books, Cheselden chose to address anatomical knowledge, in the form of books and lectures, squarely to genteel, non-specialist listeners and readers (although he also continued to publish cheap books for medical students). ${ }^{17}$ In doing so, he was emulating what many of his contemporaries were undertaking to win prestige in the fiercely competitive London medical scene. Richard Mead, for example, arranged the publication of a second edition of William Cowper's Myotomia Reformata (1724), a work that had been issued as a plain and instructive octavo volume in 1694. The second edition, by contrast, is a lavish folio featuring large numbers of finely executed prints by the fashionable engraver Michael Vandergucht. ${ }^{18}$ Subsequently, in making the Osteographia, Cheselden and his engraver, Michael's son Gerard, drew heavily on the layout of historiated initials, head- and tail-pieces established in the Myotomoia Reformata.

The Osteographia was an expensive book, both for its maker and its purchasers. When Cheselden advertised it for subscription in 1727, he offered copies of the book for four 
guineas each. To indicate that the books would always remain valuable objects, he promised to print no more than 300 copies. ${ }^{19}$ By 1740 Cheselden was poised to guarantee the value of the books forever by making certain that no more could be printed. He promised, in an advertisement affixed to the fifth edition of the Anatomy of the Humane Body, that he would 'break all the plates [of the Osteographia], which will sufficiently secure my promise to the subscribers. ${ }^{, 20}$ In the advertisement of 1727 Cheselden also saw fit to inform the public that the plates for the Osteographia had cost a great deal of money - 600 guineas in all. ${ }^{21}$ By 1740 he had sold only 97 of the books to subscribers. ${ }^{22}$ If the plates really had cost Cheselden 600 guineas to make, then he must have made a substantial loss. At the original price of four guineas per book, he would have lost at least 212 guineas on the cost of the plates alone. By 1740 Cheselden had started cutting up the books and selling the plates as separate sets, perhaps to be used as 'proper ornaments for a surgery'. ${ }^{23}$

The sumptuousness promised by the price of the book and the alleged cost of the plates is carried through in its material execution. The unnumbered pages are of very thick paper, folded to folio size, and there are 225 of them in all. The 56 plates showing the human bones are repeated in their entirety, to give 112 of these plates in total. The plates are presented once without any type of explanation, and a second time with key letters referring to brief explanations or names on the left-hand facing page (Figure 1). Of the remaining 113 pages, thirteen more are full-page engravings. The first of these is a frontispiece depicting the Roman physician Galen chancing upon the skeleton of a dead thief (Figure 2). The figure of Galen is modelled after a figure in an etching by the Italian painter Salvator Rosa (16151673), depicting the Greek cynic Diogenes of Sinope casting away his bowl after happening upon someone who was able to drink using only his hands. ${ }^{24}$ Others include a frontispiece to the dedication with the Queen's arms and a plate that does homage to Vesalius's De Humani Corporis Fabrica (1543). Moreover, there are frontispieces for the epistle to the reader and 
the introduction, as well as for each of the eight chapters. All of these latter frontispieces depict animal skeletons or parts of them. In addition to the full-page prints, each chapter is adorned with an engraved head- and tail-piece, as well as a copperplate historiated initial (an example of one of the headpieces may be found in Figure 3$).{ }^{25}$ In sum the Osteographia contains 225 pages, of which 125 are full-page plates. There are 100 pages of text, of which 56 are descriptions of the representations in the plates. Only 44 pages are given over to the chapters themselves - that is, to sustained descriptions of the bones or discussions of their workings. Moreover, many of these pages are also adorned with engravings of animal bones and skeletons.

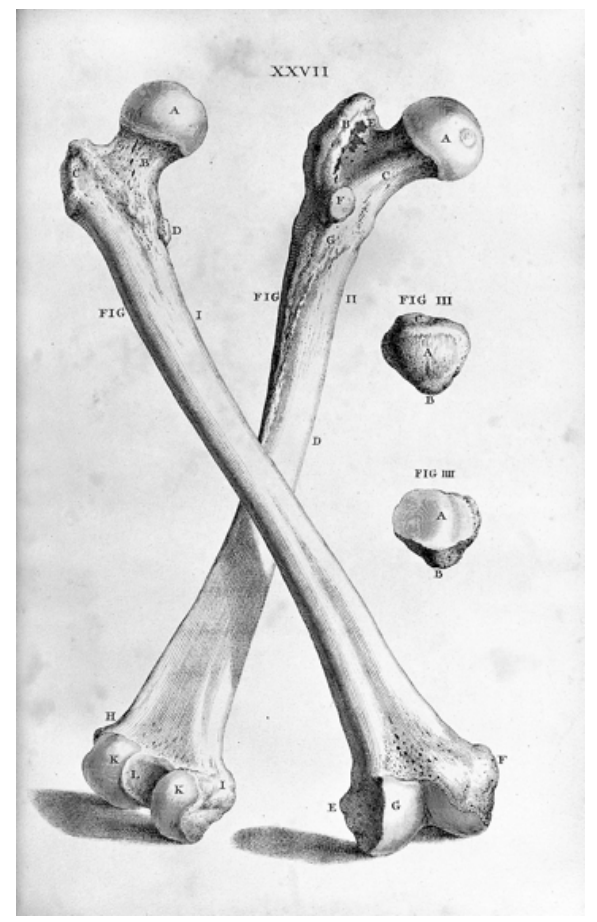

Figure 1: The lettered version of Table XXVII from Cheselden's Osteographia, depicting the femur and patella from the front and rear. Wellcome Library, London. 


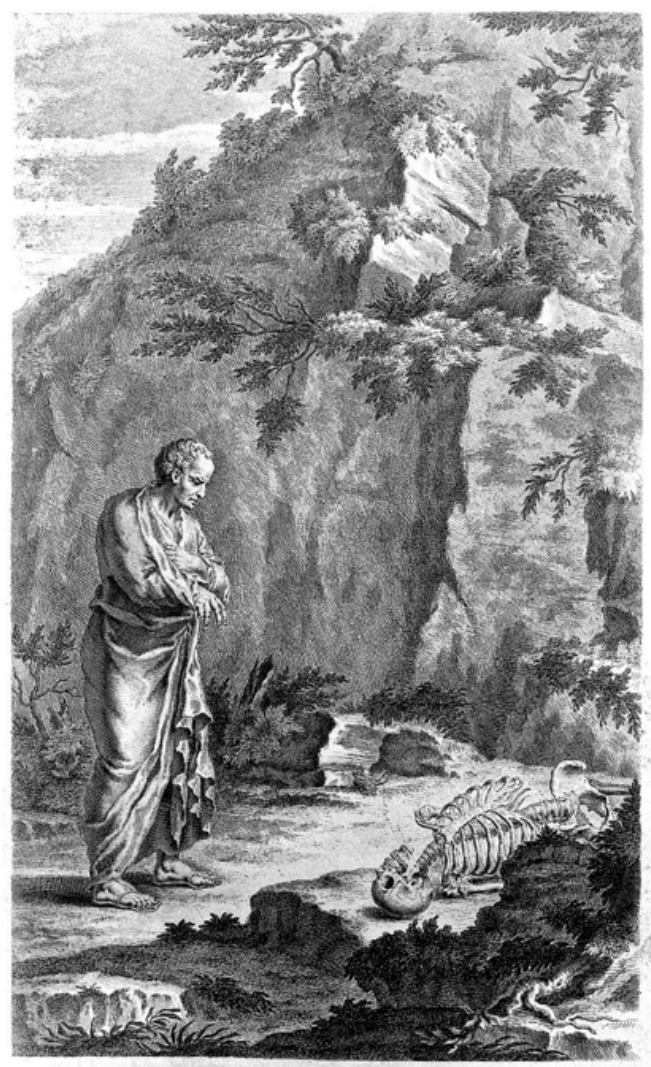

Figure 2: Frontispiece to the Osteographia depicting Galen happening upon a skeleton. Wellcome Library, London.

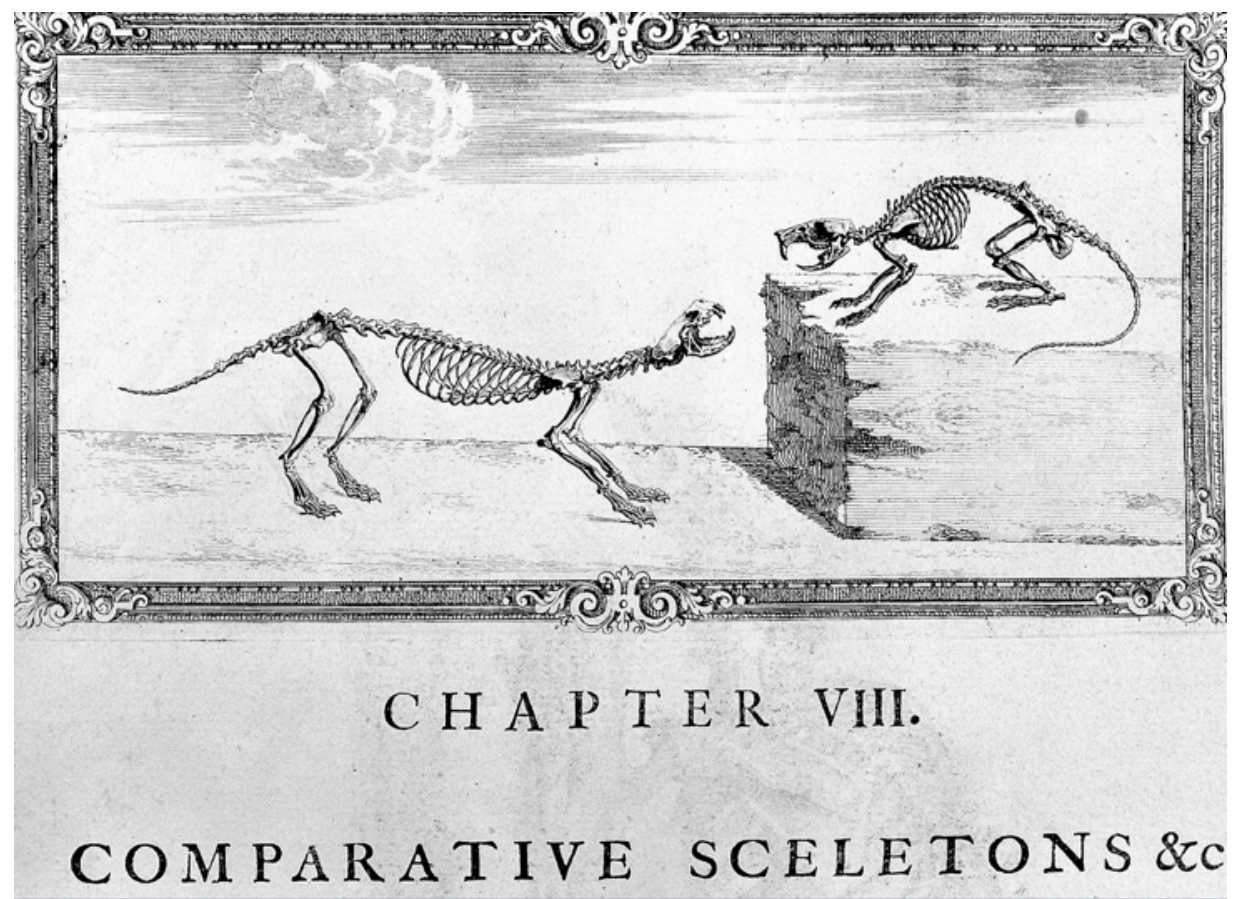

Figure 3: Head-piece depicting the skeletons of a weasel and a rat, from Chapter VIII of the Osteographia. Wellcome Library, London. 
To draw all of the bones and to make prints from the resulting draughts, Cheselden employed Gerard Vandergucht, the most fashionable and capable artist-engraver then working in London, along with Jacobus Schijnvoet, about whom very little is now known. Although Cheselden gave some indication that he esteemed Vandergucht and Schijnvoet as skilful practitioners of their art, he was at pains to demonstrate that the accuracy of the plates flowed from his role in the project. Indeed, Cheselden praised the artists for understanding that, unaided, their skills were inadequate to the task of anatomical representation: 'my engravers, Mr. Vandergucht and Mr. Shinevoet not less skilled in drawing than in their own proper art [engraving], knew too well the difficulties of representing irregular lines, perspective, and proportion, to despise such assistance'. ${ }^{26}$ Cheselden's philosophical authority guaranteed the accuracy of the plates:

The actions of all the skeletons both human and comparative, as well as the attitudes of every bone, were my own choice: and where particular parts needed to be more distinctly expressed on account of the anatomy, there I always directed; sometimes in the drawings with the pencil, and often with the needle upon the copper plate, and where the anatomist does not take this care, he will scarce have his work well performed. ${ }^{27}$

Many statements like this can be found in $17^{\text {th }}$ - and $18^{\text {th }}$-century illustrated scientific books. Such claims were conventional and sought to help readers to view representations of anatomical and philosophical subjects as epistemologically useful, in spite of the role played by non-anatomists and non-philosophers in their production. ${ }^{28}$ 
Even when he came to discuss the work of etching and engraving the philosophically accurate images onto copper plates, something that might be considered the proper province of Vandergucht and Schijnvoet, Cheselden broadcast his own involvement. Consider, for example, his discussion in the epistle to the reader of the style of Vandergucht's etching and engraving. It begins with praise: 'how great an artist he is, the open and free stile [sic.] in which these plates are etched and engraved, and the inimitable manner of expressing the different textures of the parts sufficiently shew. ${ }^{29}$ Largely through his adeptness in etching, which permits a far greater tonal range than is afforded by engraving straight into copper plates, Vandergucht had managed to produce a very fine impression of the different textures of the bones. Not much further on, however, Cheselden asserted that he himself had a hand in ensuring that the representation of the textures and surfaces of the bones was as vivid as possible. He took credit, rather dubiously, for the idea of better representing the smoothness of the ends of bones (those parts that fit into the sockets of joints) by means of strokes engraved into the copper plates with a burin, while etching all the rest. ${ }^{30}$ 


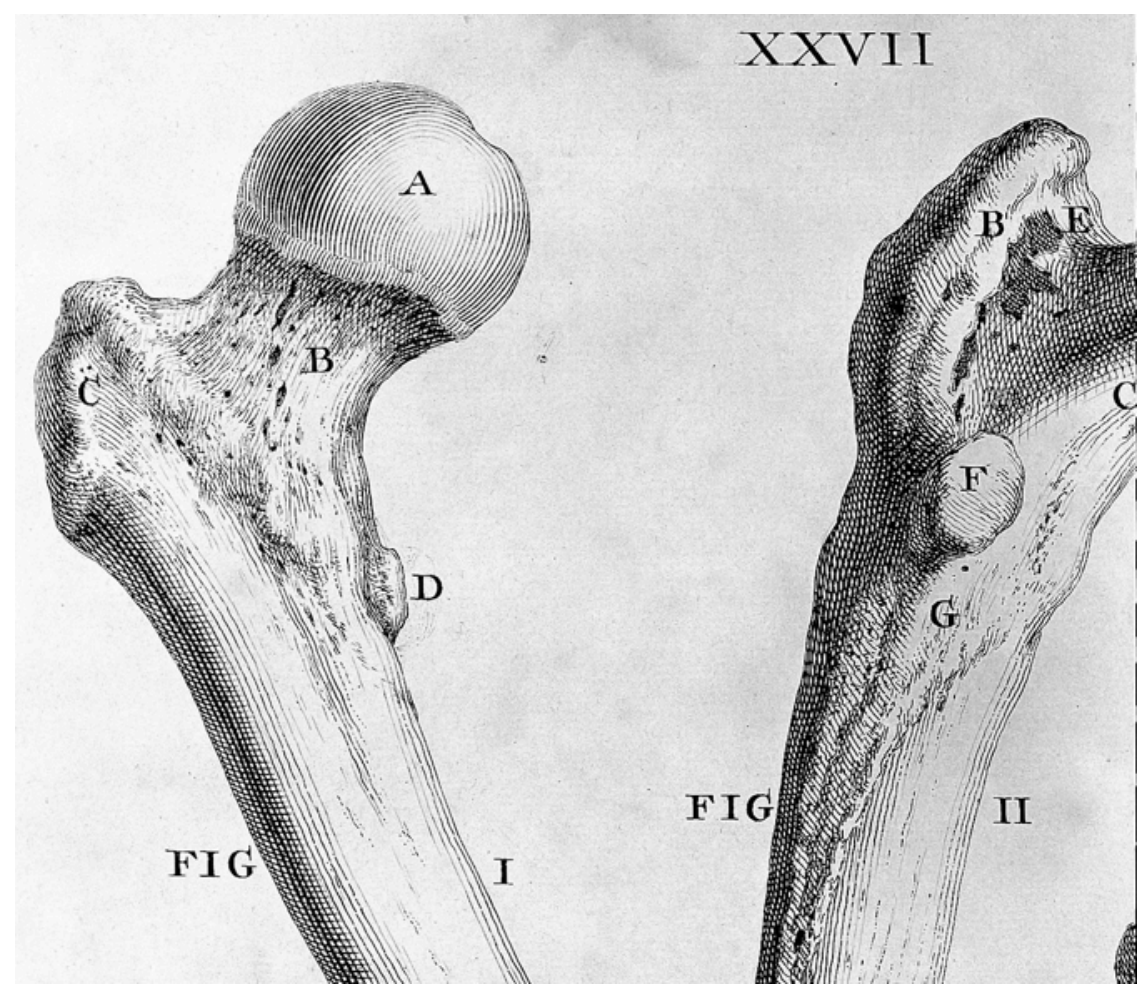

Figure 4: Detail of the lettered version of Table XXVII from Cheselden's Osteographia. The rounded end of the femur labelled ' $\mathrm{A}$ ' has been engraved with a burin, while the rest of the image is etched. Wellcome Library, London.

The technique is readily apparent in the depiction of the ends of the bones in Tab. XXVII (Figure 4). The forceful, thick and regular impressions left by the burin (with characteristic tapering towards the ends of the strokes) give the ends of the bones a texture that is distinct from all the other parts of the bones. These are represented with the lighter, thinner and less regular impressions that characterise Vandergucht's etching. We should not, I think, see this as yet another guarantee that the representations were the product of Cheselden's mind, and thus philosophically sound. Cheselden here identified himself as someone who was involved in the stylistic and technical work of image-making and reproduction. In fact, he took credit for creating a better effect of smoothness than might otherwise have been adequately achieved, not for having improved the accuracy of the representations. 
Thus the whole tenor of the Osteographia, and Cheselden's account of his involvement in its production, is that of useful instruction carried out in a sumptuous, pleasurable and expensive medium. Even its most obviously decorative components, the frontispieces, head- and tailpieces depicting animal bones, were to be understood as simultaneously ornamental and usefully instructive. Since the Osteographia has no contents page, the reader is surprised to discover that the eighth chapter, 'Chapter VIII. Comparative Sceletons etc.', contains an account of all of the things that the decorative plates depict. Positioning the frontispieces, head- and tailpieces as a kind of supplementary course in comparative anatomy, the chapter includes some details about the functioning of the bones and skeletons displayed. ${ }^{31}$ The review of the Osteographia in the Royal Society's Philosophical Transactions, written by Cheselden's apprentice John Belchier, unsurprisingly concurs with this assessment of the plates. ${ }^{32}$ So we can see that Cheselden's engagement with the materiality of his book, expressed largely in his advertisements and in his discussions of the work's plates, reflected his concern to give the book epistemological, aesthetic and moral credibility in his chosen social setting. By describing the cost of the plates, the techniques of their production and his final responsibility for these, Cheselden hoped to establish them as tasteful objects for consumption that nevertheless provided useful knowledge.

\section{John Douglas's Animadversions}

John Douglas's Animadversions on a Late Pompous Book, Intituled, Osteographia: or, The Anatomy of the Bones, in spite of its bias, contains a range of important critical responses to almost every intellectual and material aspect of the Osteographia. ${ }^{42}$ While Douglas drew negative conclusions, he accepted the premises and terms of Cheselden's positioning of the Osteographia almost entirely. He agreed that a work of osteology for non-specialist readers 
should be a beautiful and desirable object, basing his attack to a large extent on what he took to be Cheselden's failure in making such an object. Using terms drawn from connoisseurship, he concluded that the Osteographia was not fit for consumption by a genteel audience, and that its maker - Cheselden - possessed poor judgment in the arts and, crucially, in anatomy and surgery, too. With an advertisement placed at the end of his pamphlet, Douglas proposed the publication of a new book to replace the Osteographia. It was to be an expensive consumer good that pleased as much as it instructed, as Douglas promised, 'a Really useful, as well as a beautiful work' ${ }^{33}$ It would have been more modest than the Osteographia since it was to be printed in quarto but it would nevertheless have been expensive, costing two guineas, and it would have contained a large number of high-quality engravings. Douglas promised, moreover, that the plates would be produced using the same techniques that Cheselden had employed. That is, they were to be for the most part etched, and then touched up with line engraving to make them vivid and expressive. ${ }^{34}$ Douglas, then, embraced, and sought to emulate, the luxurious and beautiful form of the Osteographia.

Rather than dismiss Cheselden's project, Douglas thus proceeded by attempting to demonstrate that Cheselden had failed to make a book as beautiful and useful as was suggested by its high price. His commentary on the book's plates, which takes up the final quarter of the Animadversions, shows in particularly sharp relief how he marshalled the materiality of the Osteographia against the moral and intellectual credibility of its author. By showing that the work's plates were in many respects deficient - neither beautiful nor especially useful - and by showing them to be emanations of Cheselden's own mind, he could trace a direct link from the former to the latter. Indeed, Douglas did his utmost to paint Cheselden as a man who had acted out of pride and vanity, and with conspicuous laziness the sorts of moral characteristic that were likely to corrupt his judgment. Strikingly, he sought evidence for Cheselden's vanity in the cost and sumptuousness of the Osteographia's plates, 
as well as in the poorly-judged account of his own role in their design and production. The Osteographia was, he asserted, excessively costly, its price bumped up by the repetition of the entire set of 56 anatomical plates for no considerable purpose. ${ }^{35}$ Moreover, Cheselden could only have gone to such a great expense, and tolerated such severe losses, because his motivation in publishing the Osteographia was an excessive pride and regard for his own hypotheses: 'I cannot imagine what would move a man to set out with a view of being 400 guineas out of pocket! except innate -----y [vanity], and ----e [pride]. ${ }^{36}$ This is representative of the procedure deployed by Douglas throughout the Animadversions. He used a critical discussion of some aspect of the Osteographia to make insinuations about Cheselden's character. On account of these, he argued, Cheselden was unfit to make the sorts of judgments, either in anatomy or in matters of taste, necessary for an anatomical work to be truly beautiful and useful.

Douglas also attacked Cheselden's account of his involvement in the production of the plates and of his relationship to his artist-engravers, Vandergucht and Schijnvoet. Cheselden's account of his working relationship with Vandergucht and Schijnvoet was, Douglas explained, nothing more than 'a sneer on the Painters and Engravers, and an Encomium on himself, as being their Director. ${ }^{37}$ There was nothing exceptional about the commissioner of an artwork or illustration giving directions as to what he wanted to be drawn and engraved, and pointing out those features deserving of particular attention:

don't every one who employs a Painter, tell him whether he would have him paint a Busto, a half length, or a whole length, or in what posture he would choose to be drawn? does not every man, who has a Sign to be painted, do the same? [...] What an harangue is here, as if he had done something 
extraordinary, which never was done before! there I always directed! i.e. when he set the scull down before the Painter, he took his probe, and pointed out the Sutura Transversalis, Os Unguis, Septum Nasi, \&c. and said, be sure, Sir, to delineate these little parts fairly, \&c. [...] Have not all the Anatomists upon earth done so? $?^{38}$

Douglas did not dispute the extent of Cheselden's participation in the intellectual and material realization of the Osteographia or argue that the division of labour that he described was inappropriate. Instead he explained that such practices as choosing the parts to be represented and specifying the exact manner of their depiction were the regular and normal practices of the connoisseur and the anatomist. It followed, therefore, that Cheselden had made excessive claims for his own involvement because of his vanity. Once again, Douglas claimed to have exposed the true motivation for Cheselden's behaviour. He had made a pompous book with too many engravings, trumpeted his role in their production immodestly, and shouldered an enormous financial loss, all because he was vain. ${ }^{39}$

Douglas thus mobilised the ideals and practices of connoisseurship to demonstrate that Cheselden was a man of poor character, and that his Osteographia was a bad book. In a series of very detailed, and often penetrating, critical discussions of every single plate and paragraph, he drew links between Cheselden's capacities as a connoisseur and his ability to make sound judgments of medical and anatomical matters. Douglas proceeded with two distinct forms of criticism. The first was designed to expose Cheselden's failures in strict matters of anatomical judgment. It consisted mainly in arguing that he had chosen to represent things that were not valuable, all the while neglecting those things that could have contributed usefully to the work. Importantly, he applied these criticisms both to the 
anatomical plates themselves, and to the book's decorative elements. He asked, for example, why Douglas had used the frontispieces, head- and tail-pieces to represent anatomical skeletons. For Douglas, these plates contributed little to the work since they did nothing to explicate the human bones represented at large in the book. They could have been even more beautiful and instructive if they had represented the parts of the human body dependent on the skeleton for their functioning:

[...] if he had been as solicitous about making his work useful as pompous, i.e. all of a piece, both in contrivance and goodness of work, he might for the same expence, have filled the places of these useless monsters, with other parts of the human body, which would have been more beautiful, and very instructive $^{40}$

Douglas fashioned his comments on the anatomical plates and their labelling after the same pattern. Everywhere, he identified images in the plates that ought never to have been included - 'good for nothing, but to fill up gaps' - and others that either did not include subjects of importance or included them without sufficient explanation to make their importance apparent. Cheselden's plates were the work of a confused judgment. He had failed to distinguish between those anatomical subjects that might have given edification and those that had no place in a work of osteology. ${ }^{41}$

The second set of criticisms concerned Cheselden's taste, and again Douglas applied these criticisms equally to the anatomical plates and the decorative elements. Moreover, he called Cheselden's judgments of taste into question in much the same manner as he had the 
his anatomical choices - by trying to show that he had chosen to represent things that were not beautiful, while rejecting those things that might have beautified the book. Commenting on the anatomical plates, Douglas argued that those which he had dismissed as contributing little to osteological knowledge also detracted from the book because of their ugliness. He rejected a series of plates depicting diseased bones as 'a parcel of rotten bones, and all incurable cases, not worth delineating. ${ }^{, 42}$ Similarly, he cast many of the decorative plates as not only useless, but inelegantly so. Consider, for example, his treatment of the frontispiece and headpiece adorning the letter to the reader. The frontispiece depicts a male deer stopping and turning, while the headpiece represents a sleeping dog. Although Douglas had already registered his fundamental disagreement with the choice of animal skeletons for these plates, he nevertheless judged the plates on their individual qualities. He found the frontispiece, depicting 'the sceleton of a young buck, stopping suddenly and turning', 'not only well contrived, but also very well executed'. Yet he objected in strong terms to the headpiece, which displays a dog lying asleep. The buck at least made an agreeable sight for the book's purchasers. But what of the sleeping dog?

Pray, is there no posture of a Dog more graceful, than when he is asleep? Would not the figure of a fine Greyhound bounding over the field, when eagerly expecting his game, have made a more agreeable print, than a CurDog asleep $[\ldots] ?^{43}$ 
Douglas therefore argued that the purposelessness that he had identified in the decorative plates was matched by the poor taste in which they had been chosen. The majority, he declared, hardly presented a fit sight for the purchasers of such an expensive book.

To understand Douglas's response to Cheselden's book, we must recognise that Douglas chose, at least in the Animadversions, to agree that osteological knowledge should be presented in a beautiful, expensive form. The way to discredit Cheselden, then, was to show that the Osteographia was not truly as valuable as had been advertised. This was to be achieved by inverting the values assigned by Cheselden to the formal, material and intellectual aspects of the book. Cheselden had used his own intellectual involvement, the book's cost and the techniques of its production to show that it had aesthetic, epistemological and pecuniary value. As I have argued, Douglas's criticisms of Cheselden were motivated in part by an attempt to portray Cheselden as a disingenuous sort of person. He represented the Osteographia as a grand piece of misrepresentation, as if it had been designed (albeit without success) to distract the public from an appreciation of his real capacity for aesthetic, anatomical and medical judgments alike.

\section{Connoisseurship and the Communication of Anatomical Knowledge}

Cheselden's presentation of the materiality of the Osteographia, and Douglas's detailed engagement with that materiality show us that eighteenth century discourses and practices that may usefully be grouped under the heading 'connoisseurship' could animate the production and consumption of an anatomical book in a consequential fashion. The fact that medics like Cheselden preoccupied themselves with both medical matters and with connoisseurship is less significant than the fact that he and his contemporaries, including a 
vengeful antagonist, felt that the values of connoisseurship could usefully be applied to the making and consuming of certain forms of anatomical and medical knowledge.

The status of books like the Osteographia as beautiful, expensive consumer goods was of consequence to their valuation as useful or not-so-useful sources of knowledge. This is demonstrated by the range of associations that both Cheselden and Douglas gave to the Osteographia in its totality, from the size of its pages and the expense lavished on its prints, to the exact representational choices made in the plates and descriptions. The manner in which Cheselden and Douglas swiftly linked the materiality of the Osteographia to the moral status of the person responsible for its form is important to our understanding of the interplay between connoisseurship and anatomical/medical knowledge. They used the evidence of a range of good or bad judgments, whether pertaining to anatomy proper or to matters of taste, to make more general suggestions about the capacity of the Osteographia's maker to serve as the guarantor of real anatomical knowledge. In other words, Cheselden's ability to judge properly of the tastefulness of his decorative head-and tailpieces could usefully serve as evidence for his anatomical judgment, and vice-versa. Additionally, Douglas tried to argue that there was a gap between the claims that Cheselden made for the beauty and utility of his book, and the book's real qualities. This failure of connoisseurship made Cheselden into a sort of impostor, someone who claimed to possess qualities that in reality he lacked.

This brings us back full-circle to the surgical priority dispute that had first so inflamed Douglas's hatred for Cheselden. Little is known about Robert Houston, the author of Lithotomus castratus; or, Mr. Cheselden's treatise on the high operation for the stone, throughly examin'd, and plainly found to be Lithotomia Douglassiana, except that he was a medical doctor who supported Douglas's claim. It is worth paying close attention, however, to the manner in which he tried to demonstrate that Cheselden had merely copied Douglas's 
lithotomy procedure. Surgery hardly figures at all in Houston's polemic. Instead, he chose to treat the accounts of the procedure offered by Cheselden and by Douglas as artefacts with which the moral status of their makers might be found out. By comparing Cheselden's description of the surgery with that offered by Douglas, he tried to show that the former was simply a copy of the latter. This made Douglas a virtuous discoverer and sharer of knowledge and made Cheselden a prideful fraud: 'it [Cheselden's account] looks at best, like a poor and ill-design'd endeavour of one artful and crafty man, to pass for what he is not ${ }^{\text {,44 }}$. Even in the surgical priority dispute that led Douglas to engage in his aggressive criticism of the plates of the Osteographia, practices closely resembling those of connoisseurship had an important role to play in helping readers to form an opinion about the true origins of the procedure and the true nature of those who purported to have invented it.

I would like to end this article by suggesting that by paying closer attention to eighteenth century worries about the use of the senses we might be able better to understand why connoisseurship and medical knowledge were so closely connected. As is well known, the turn of the eighteenth century marked a decisive shift in the emergence of a consumer culture, especially in centres of commerce such as London. It is equally well known that this proliferation of consumer goods provoked worried among members of the cultural and intellectual elite. As Preben Mortensen has noted, there were those in eighteenth century England who aired the concern that the sensory pleasures provoked by luxurious things would lead people to use their senses in the pursuit of gratifications that would ruin their morals. Such was the dim view of these things taken by many members the Society for the Reformation of Manners, a group which sought to curb immorality in London around the turn of the eighteenth century. Even more unsettlingly for the upholders of conventional morality, the philosopher Bernard Mandeville argued in his The Fable of the Bees (1714) that the consumption of luxuries was motivated by private vices, but that these vices taken together 
produced the public benefit of ever-greater prosperity. ${ }^{45}$ Surely Cheselden and Douglas could not have agreed with Mandeville's pessimistic assessment. Had they agreed wholeheartedly with the moral of The Fable of the Bees they would have had to accept that their readers likely had sinful motives for buying luxurious books like the Osteographia.

In the face of such worries theorists of art and philosophers alike tried to show that it was not only possible to reconcile sensory gratification with the pursuit of virtue, but that the cultivation of good taste in the arts, antiquities and books could help people further along the path of virtue. Cheselden's friend Jonathan Richardson (1676-1745), the painter and art theorist, argued that the formation of good taste in paintings was consequential far beyond its immediate sphere of application. In his Essay on the Whole Art of Criticism as it relates to Painting (1719), he took time in several places to distinguish the morally-improving edification to be gained by looking upon tasteful paintings from the 'Impertinent, or Criminal Amusements' to be had by receiving sense impressions from the wrong things. ${ }^{46}$ This was a theme that the philosopher Francis Hutcheson picked up in his An Inquiry into the Original of our Ideas of Beauty and Virtue (1725). In that work and others he argued that those who could make proper judgments about beauty must also be capable of good moral judgments and that, conversely, those who could not rightly perceive beauty were also very unlikely to be able to make good moral judgments. ${ }^{47}$ Richardson too, albeit without resorting to a radically new aesthetic theory as had Hutcheson, argued that the ability to make good judgments about art betokened an ability to make a range of other judgments, including being able to tell the difference between those pleasures corresponding to virtue and those that corresponded to bad behaviour. Indeed, Richardson argued (after the fashion of John Locke) that the exercise of judgment, regardless of its subject, consisted in the distinction of ideas from each other. Therefore, this was 'as necessary to a Connoisseur as to a Philosopher, or 
Divine to be a good Logician; The Same Faculties are employ'd, and in the Same manner, the difference [was] only in the Subject. ${ }^{48}$

In response to concerns, which they often expressed themselves, about the possibility that the new world of luxury goods could lead people away from the path of virtue, Richardson and Hutcheson tried to show that what connoisseurs did when they judged beautiful and expensive things made them more virtuous. However, this also led them to argue that failures of connoisseurship were not necessarily simple errors, but perhaps indicative of much broader failures of judgment. Richardson, as we have seen, claimed that connoisseurs made use of just the same faculties and procedures for thinking about paintings as they might use in matters of philosophy and logic. Hutcheson even claimed that the capacity to recognise beauty was inherently related to the capacity to make moral judgments. In this piece I have shown that, in his criticism of the Osteographia, Douglas drew similar links between Cheselden's capacities as a connoisseur and his moral state. Perhaps this was because he also believed, or chose to appear to believe, that failures to judge well in matters of taste betokened deeper intellectual and moral failings. This could help to explain why Cheselden, Douglas and their contemporaries in the world of medicine attached so much consequence to acts of connoisseurship. Much could be inferred about the intellectual and moral states of those who offered public judgments about the qualities of luxurious things.

Acknowledgments: I am very grateful for the opportunity afforded to me by the organizers of the 'Material Cultures of the Long Eighteenth Century' workshop at the Huntington Library (April, 2012), Adriana Craciun and Simon Schaffer, to present my work at that event, and for the subsequent opportunity to publish it in this volume. I am also very grateful for the helpful 
comments on this work from Rebecca Addicks, Rebecca Bowd, Sarah Easterby-Smith, Craig Ashley Hanson, Simon Schaffer and Anna-Marie Roos. I am as ever extremely happy to acknowledge the help and support of Cécile Bishop.

${ }^{1}$ J. Stolnitz, 'On the Origins of "Aesthetic Disinterestedness", The Journal of Aesthetics and Art Criticism 20:2 (1961), 131-143, on 131-32.

${ }^{2}$ L. Daston and K. Park, Wonders and the Order of Nature, 1150-1750 (New York: Zone Books, 2001), 355.

${ }^{3}$ E. Spary, 'Scientific Symmetries', History of Science 42 (2004), 1-46; J. Riskin, Science in the Age of Sensibility: the Sentimental Empiricists of the French Enlightenment (Chicago: University of Chicago Press, 2002); C.A. Hanson, The English Virtuoso: Art, Medicine, and Antiquarianism in the Age of Empiricism (Chicago: University of Chicago Press, 2009).

${ }^{4}$ In using the term 'connoisseurship' I simply wish to note that a great part of their activity consisted not only in aesthetic criticism but in appraising the authenticity and value of artistic and antiquarian objects. I am therefore indebted to the large number of works on the history of connoisseurship in the eighteenth century, especially the ways in which connoisseurship was contested among the partisans of different artistic styles. A recent and instructive example is H. Mount, 'The Monkey with the Magnifying Glass: Constructions of the Connoisseur in Eighteenth-Century Britain', Oxford Art Journal 29 (2006), 167-184.

${ }^{5}$ As Jordanova shows, the size and scope of Mead's collection can be gathered from the auction catalogues printed in advance of its sale. His paintings, prints, drawings, sculptures, medals and coins were divided into three main sales, detailed in A catalogue of the genuine 
and capital collection of pictures [...] of that late great and learned physician, Doctor Richard Mead (London, 1754); A catalogue of the genuine, entire and curious collection of prints and drawings [...] of the late Doctor Mead (London, 1755); and A catalogue of the genuine and entire collection of valuable gems, bronzes, marble and others busts and antiquities, of the late Doctor Mead (London, 1755). His library was also sold off and catalogued in Bibliotheca Meadiana, sive Catalogus Librorum Richardi Mead (London, 1754).

${ }^{6}$ L. Jordanova, 'Portraits, People and Things: Richard Mead and Medical Identity', History of Science 41 (2003), 293-313, on 307. Jordanova derives this from the biographical account of Mead offered in W. MacMichael, The Gold-headed Cane, $2^{\text {nd }}$ edn (London, 1828), 109.

${ }^{7}$ Cheselden advertised the work for potential subscribers in the London Daily Journal on each day that it came out from April $18^{\text {th }}-$ May $1^{\text {st }}, 1727$.

${ }^{8}$ See for example M. Terrall, 'Natural Philosophy for Fashionable Readers,' in Books and the Sciences in History, ed. M. Frasca-Spada and N. Jardine (Cambridge: Cambridge University Press, 2000), 239-254.

${ }^{9}$ John Douglas, Animadversions on a Late Pompous Book, Intituled, Osteographia: or, The Anatomy of the Bones (London, 1735).

${ }^{10}$ W. Cheselden, 'An Account of Some Observations Made by a Young Gentleman, Who Was Born Blind, or Lost His Sight so Early, That He Had no Remembrance of Ever Having Seen, and Was Couch d between 13 and 14 Years of Age', Philosophical Transactions 35 (1727-1728), 447-450. The best account of Cheselden's account and its role in the works of Condillac is J. Riskin, Science in the Age of Sensibility: the Sentimental Empiricists of the 
French Enlightenment (Chicago: University of Chicago Press, 2002), 19-67. On Edmund

Burke's use of a racially-charged moment in this account in his aesthetic theory, see M. Armstrong, ""The Effects of Blackness": Gender, Race, and the Sublime in Aesthetic Theories of Burke and Kant', The Journal of Aesthetics and Art Criticism 54 (1996), 213-36, on 219-220.

${ }^{11} \mathrm{~W}$. Cheselden, A treatise on the high operation for the stone (London, 1723).

${ }^{12}$ R. Houstoun, Lithotomus Castratus; or, Mr Cheselden's Treatise on the High Operation for the Stone, thoroughly examin'd, and plainly found to be Lithotomia Douglassiana [...]. (London, 1723).

${ }^{13}$ James Douglas, The History of the Lateral Operation: or, an account of the method of extracting a stone by making a wound near the great protuberance of the Os Ischium (London, 1726) and An appendix to the history of the lateral operation for the stone. Containing Mr Cheselden's present method (London, 1731).

${ }^{14}$ By 1792 , thirteen editions of the work had been printed.

${ }^{15}$ I. Bignamini and M. Postle, The Artist's Model: Its Role in British Art from Lely to Etty (Nottingham: Nottingham University Art Gallery, 1991), 10.

${ }^{16}$ Bignamini and Postle, The Artist's Model, 12-13, 86; J. Kirkup, “Cheselden, William (1688-1752)," in Oxford Dictionary of National Biography, ed. H. C. G. Matthew and Brian Harrison (Oxford: OUP, 2004); online ed., ed. Lawrence Goldman, October 2006, http://www.oxforddnb.com/view/article/5226 (accessed July 15, 2013). 
${ }^{17}$ In the $1^{\text {st }}$ edition of his Anatomy of the Humane Body, Cheselden explained that he intended his book to be read by those who 'study Anatomy for their Entertainment'. See W. Cheselden, The Anatomy of the Humane Body, $1^{\text {st }}$ edn (London, 1713), vii. In a number of his other published works, and in advertisements for public lectures, Cheselden made similar statements, explaining that his audiences would not be troubled by anything displeasing or tedious. See for example: an advertisement placed in the Daily Courant No. 6057, 21 March,1721; W. Cheselden, The Anatomy of the Human Body, $5^{\text {th }}$ edn (London, 1740), preface (unpaginated); W. Cheselden, Osteographia, or The Anatomy of the Bones (London, 1733), epistle to the reader (unpaginated).

${ }^{18}$ W. Cowper, Myotomia Reformata, or an Anatomical Treatise on the Muscles of the Human $\operatorname{Body} 2^{\text {nd }}$ edn (London, 1724). See C. A. Hanson, 'Anatomy, Newtonian Physiology and Learned Culture: The Myotomia Reformata and its Context within Georgian Scholarship', in Anatomy and the Organization of Knowledge, 1500-1850, ed. M. Landers and B. Muñoz (London: Pickering \& Chatto, 2012).

${ }^{19}$ W. Cheselden, advertisements placed in the London Daily Journal on each day that it came out from April $18^{\text {th }}-$ May $1^{\text {st }}, 1727$.

${ }^{20}$ Cheselden, Anatomy, $5^{\text {th }}$ edn (London, 1740), 'Advertisement' (unpaginated).

${ }^{21}$ Cheselden, advertisements in the London Daily Journal, April $18^{\text {th }}-$ May $1^{\text {st }}, 1727$.

${ }^{22}$ Cheselden, Anatomy $5^{\text {th }}$ edn (London, 1740), 'Advertisement' (unpaginated), 'There were two hundred and three remaining after the subscribers had their books, four score and three of which I have cut to pieces.'

${ }^{23}$ Ibid., 'Advertisement' (unpaginated). 
${ }^{24}$ J. Belchier, 'An Account of a Book: Osteographia, or, the Anatomy of the Bones by William Cheselden', Philosophical Transactions, 38 (1733 - 1734), 194-98, on 195. Belchier was Cheselden's apprentice. Although Belchier does not explain exactly which of Salvator Rosa's prints the figure in the frontispiece was based on, it is clearly derived from 'Diogenes Casting Away his Bowl', Salvator Rosa, Rome, 1661-1662, which may be found in the Victoria and Albert Museum, London (Museum number 24448).

${ }^{25}$ The Osteographia's initials, along with its head- and tail-pieces, are stylistically similar to those in Cowper's Myotomia Reformata, $2^{\text {nd }}$ edn (London, 1724). On Cowper's initials, see M. A. Sanders, 'William Cowper and his Decorated Copperplate Initials', The Anatomical Record Part B: The New Anatomist, 282:1 (2005), 5-12.

${ }^{26}$ Cheselden, Osteographia, Epistle to the Reader (unpaginated).

${ }^{27}$ Ibid.

${ }^{28}$ Consider for example this disclaimer in Nehemiah Grew's The Anatomy of Plants. With an Idea of a Philosophical History of Plants, And several other Lectures, Read before the Royal Society (London, 1682), Preface (unpaginated), 'Some of the Plates, especially those which I did not draw to the Engravers hand, are a little hard and stiff: but they are all well enough done, to represent what they intend.'

${ }^{29}$ Cheselden, Osteographia, Epistle to the Reader (unpaginated).

${ }^{30}$ Ibid.

${ }^{31}$ Cheselden, Osteographia, 'Chapter VIII. Comparative Sceletons etc.' (unpaginated). 
${ }^{32}$ J. Belchier, 'An Account of a Book: Osteographia, or, the Anatomy of the Bones by William Cheselden', 197.

${ }^{33}$ Douglas, Ibid., 28.

${ }^{34}$ J. Douglas, 'Proposals for Printing (in Quarto) by Subscription, Osteographia AnatomicoPractica', attached at the very end of the Animadversions.

${ }^{35}$ Ibid., 30.

${ }^{36}$ Ibid., 28.

${ }^{37}$ Ibid., 25-6.

${ }^{38}$ Ibid., 26.

${ }^{39}$ It is interesting to note that the engraver George Vertue, one of Gergard Vandergucht's immediate contemporaries, found Cheselden's remarks to be quite proper. As he put it, "I think the characters (Mr. Chiselden in his preface to his most excellent book of Osteology or discription of bones. of the Engravers who perform that work very skilfully are truly what they well deserve, and G. Vander Gucht has show's all the Art that possibly can be performed in such a work not excelld, or to be out done in yt part by the famousst Engravers abroad... Shinvot has also well succeed in his part, this I mention in respect to a branch of. Art I am best able to Judge of, that it will be a lasting monument to their honour, and this Nation. For perfection of Art in any part of the World is very rare.' See G. Vertue, Note Books, ed. K.A. Esdaile, H.M. Hake, G.S.H. Fox-Strangeways, 6 vols (Oxford: Walpole Society, 1930-55), vol. 3 (printed as the $22^{\text {nd }}$ volume of the Walpole Society), 77.

${ }^{40}$ Ibid., 30. 
${ }^{41}$ Ibid., 28-38. The quotation is on 32.

${ }^{42}$ Ibid., 38.

${ }^{43}$ Cheselden, Osteographia, 'Chapter VIII. Comparative Sceletons etc.' (unpaginated);

Douglas, Animadversions, 29.

${ }^{44}$ Houston, Lithotomus Castratus, 5.

${ }^{45}$ P. Mortensen, 'Francis Hutcheson and the Problem of Conspicuous Consumption', The Journal of Aesthetics and Art Criticism, 53:2 (1995), 155-65, on 156-7; B. Mandeville, The Fable of the Bees: or, Private vices publick benefits (London, 1714).

${ }^{46}$ J. Richardson, Two Discourses. I. Essay On the whole Art of Criticism as it relates to Painting [...]. II. An argument in behalf of the science of a connoisseur (London, 1719), 5.

${ }^{47}$ Mortensen, 'Hutcheson and Conspicuous Consumption', 162; F. Hutcheson, An Inquiry into the Original of our Ideas of Beauty and Virtue (London, 1725).

${ }^{48}$ Richardson, Essay On the whole Art of Criticism, 203. 


\section{Bibliography}

Anonymous, Bibliotheca Meadiana, sive Catalogus Librorum Richardi Mead (London, 1754).

, A catalogue of the genuine and capital collection of pictures [...] of that late great and learned physician, Doctor Richard Mead (London, 1754).

, A catalogue of the genuine, entire and curious collection of prints and drawings [...] of the late Doctor Mead (London, 1755).

, A catalogue of the genuine and entire collection of valuable gems, bronzes, marble and others busts and antiquities, of the late Doctor Mead (London, 1755).

M. Armstrong, "The Effects of Blackness": Gender, Race, and the Sublime in Aesthetic Theories of Burke and Kant', The Journal of Aesthetics and Art Criticism 54 (1996), 213-36.

J. Belchier, 'An Account of a Book: Osteographia, or, the Anatomy of the Bones by William Cheselden', Philosophical Transactions, 38 (1733 - 1734), 194-98.

W. Cheselden, The Anatomy of the Humane Body, $1^{\text {st }}$ edn (London, 1713).

, The Anatomy of the Human Body, $5^{\text {th }}$ edn (London, 1740).

, A treatise on the high operation for the stone (London, 1723).

, 'An Account of Some Observations Made by a Young Gentleman, Who Was

Born Blind, or Lost His Sight so Early, That He Had no Remembrance of Ever Having Seen, and Was Couch d between 13 and 14 Years of Age', Philosophical Transactions 35 (17271728), 447-450.

, Osteographia, or The Anatomy of the Bones (London, 1733).

W. Cowper, Myotomia Reformata, or an Anatomical Treatise on the Muscles of the Human Body $2^{\text {nd }}$ edn (London, 1724).

L. Daston and K. Park, Wonders and the Order of Nature, 1150-1750 (New York: Zone Books, 2001).

James Douglas, The History of the Lateral Operation: or, an account of the method of extracting a stone by making a wound near the great protuberance of the Os Ischium (London, 1726)

, An appendix to the history of the lateral operation for the stone. Containing

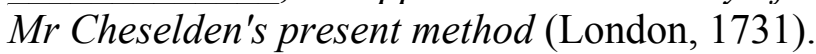

John Douglas, Animadversions on a Late Pompous Book, Intituled, Osteographia: or, The Anatomy of the Bones (London, 1735). 
N. Grew, The Anatomy of Plants. With an Idea of a Philosophical History of Plants, And several other Lectures, Read before the Royal Society (London, 1682).

C.A. Hanson, The English Virtuoso: Art, Medicine, and Antiquarianism in the Age of Empiricism (Chicago: University of Chicago Press, 2009).

, 'Anatomy, Newtonian Physiology and Learned Culture: The Myotomia Reformata and its Context within Georgian Scholarship', in Anatomy and the Organization of Knowledge, 1500-1850, ed. M. Landers and B. Muñoz (London: Pickering \& Chatto, 2012).

P. Mortensen, 'Francis Hutcheson and the Problem of Conspicuous Consumption', The Journal of Aesthetics and Art Criticism, 53:2 (1995), 155-65.

R. Houstoun, Lithotomus Castratus; or, Mr Cheselden's Treatise on the High Operation for the Stone, thoroughly examin'd, and plainly found to be Lithotomia Douglassiana [...]. (London, 1723).

L. Jordanova, 'Portraits, People and Things: Richard Mead and Medical Identity', History of Science 41 (2003), 293-313.

W. MacMichael, The Gold-headed Cane, $2^{\text {nd }}$ edn (London, 1828).

B. Mandeville, The Fable of the Bees: or, Private vices publick benefits (London, 1714).

H. Mount, 'The Monkey with the Magnifying Glass: Constructions of the Connoisseur in Eighteenth-Century Britain', Oxford Art Journal 29 (2006).

J. Richardson, Two Discourses. I. Essay On the whole Art of Criticism as it relates to Painting [...]. II. An argument in behalf of the science of a connoisseur (London, 1719).

J. Riskin, Science in the Age of Sensibility: the Sentimental Empiricists of the French Enlightenment (Chicago: University of Chicago Press, 2002).

M. A. Sanders, 'William Cowper and his Decorated Copperplate Initials', The Anatomical Record Part B: The New Anatomist, 282:1 (2005), 5-12.

E. Spary, ‘Scientific Symmetries', History of Science 42 (2004), 1-46.

J. Stolnitz, 'On the Origins of "Aesthetic Disinterestedness", The Journal of Aesthetics and Art Criticism 20:2 (1961), 131-143.

M. Terrall, 'Natural Philosophy for Fashionable Readers,' in Books and the Sciences in History, ed. M. Frasca-Spada and N. Jardine (Cambridge: Cambridge University Press, 2000), 239-254.

G. Vertue, Note Books, ed. K.A. Esdaile, H.M. Hake, G.S.H. Fox-Strangeways, 6 vols (Oxford: Walpole Society, 1930-55). 